\title{
Microstructure, Mechanical Properties and Corrosion Behavior of Extruded Mg-Zn-Ag Alloys with Single-Phase Structure
}

\author{
Hong Zhao ${ }^{1} \cdot$ Li-Qing Wang ${ }^{1} \cdot$ Yu-Ping Ren ${ }^{1} \cdot$ Bo Yang ${ }^{1} \cdot$ Song $\mathrm{Li}^{1} \cdot$ Gao-Wu Qin ${ }^{1}$
}

Received: 10 October 2017 / Revised: 6 November 2017 / Published online: 21 February 2018

(C) The Chinese Society for Metals and Springer-Verlag GmbH Germany, part of Springer Nature 2018

\begin{abstract}
$\mathrm{Mg}-\mathrm{Zn}-\mathrm{Ag}$ alloys have been extensively studied in recent years for potential biodegradable implants due to their unique mechanical properties, biodegradability and biocompatibility. In the present study, $\mathrm{Mg}-3 \mathrm{Zn}-x \mathrm{Ag}(\mathrm{wt} \%, x=0.2,0.5$ and 0.8 ) alloys with single-phase crystal structure were prepared by backward extrusion at $340{ }^{\circ} \mathrm{C}$. The addition of $\mathrm{Ag}$ element into $\mathrm{Mg}-3 \mathrm{Zn}$ slightly influences the ultimate tensile strength and microstructure, but the elongation firstly increases from $12 \%$ to $19.8 \%$ and then decreases from $19.8 \%$ to $9.9 \%$ with the increment of $\mathrm{Ag}$ concentration. The tensile yield strength, ultimate tensile strength and elongation of $\mathrm{Mg}-3 \mathrm{Zn}-0.2 \mathrm{Ag}$ alloy reach up to $142,234 \mathrm{MPa}$ and $19.8 \%$, respectively, which are the best mechanical performance of $\mathrm{Mg}-\mathrm{Zn}-\mathrm{Ag}$ alloys in the present work. The extruded $\mathrm{Mg}-3 \mathrm{Zn}-0.2 \mathrm{Ag}$ alloy also possesses the best corrosion behavior with the corresponding corrosion rate of $3.2 \mathrm{~mm} / \mathrm{year}$ in immersion test, which could be explained by the single-phase and uniformly distributed grain structure, and the fewer twinning.
\end{abstract}

Keywords $\mathrm{Mg}-\mathrm{Zn}-\mathrm{Ag} \cdot$ Single phase $\cdot$ Backward extrusion $\cdot$ Mechanical performance $\cdot$ Corrosion behavior

\section{Introduction}

Magnesium alloys have been extensively studied in recent years as potential biodegradable implants in bone and cardiovascular surgery due to their unique mechanical properties, biodegradability and biocompatibility [1-5]. Among these magnesium alloys, the $\mathrm{Mg}-\mathrm{Zn}$-based alloys have attracted much attention, since $\mathrm{Zn}$ is one of the most abundant nutritionally essential elements in human body [6-8]. To date, even though significant progress has been achieved in the performance of $\mathrm{Mg}-\mathrm{Zn}$-based alloys, the degradation behavior and mechanical properties are still unsatisfactory.

Available online at http://link.springer.com/journal/40195

Yu-Ping Ren

renyp@atm.neu.edu.cn

$\triangle$ Gao-Wu Qin

qingw@smm.neu.edu.cn

1 Key Laboratory for Anisotropy and Texture of Materials, Ministry of Education, School of Materials Science and Engineering, Northeastern University, Shenyang 110819, China
In general, the mechanical properties and degradation behavior of $\mathrm{Mg}-\mathrm{Zn}$-based alloys can be tailored by adding alloying elements such as $\mathrm{Al}, \mathrm{Ca}, \mathrm{Zr}, \mathrm{Mn}, \mathrm{Ag}$ and rare earth elements (RE) [9-25]. But the release of some elements may cause hepatotoxicity and/or neurotoxicity, such as $\mathrm{Al}$ and $\mathrm{Pb}[3,26,27]$. As far as biocompatibility is concerned, $\mathrm{Mg}-\mathrm{Zn}-\mathrm{Ag}$-based alloys have received much attention as candidates for a resorbable alloy due to its anti-inflammatory effects $[22,28]$. However, the primary use of $\mathrm{Mg}-\mathrm{Zn}-$ Ag-based alloys concentrated on structural applications, with the improvement in mechanical properties by the precipitation of secondary phases [22, 23]. Owing to their difference in chemistry in comparison with magnesium matrix, these particles possessing higher electrode potential than the matrix will induce galvanic corrosion and/or pitting corrosion, which accelerates the degradation rate of $\mathrm{Mg}$ alloys and further leads to the deterioration of mechanical properties $[29,30]$. There is lack of research on the mechanical properties and corrosion behavior of $\mathrm{Mg}$ $\mathrm{Zn}-\mathrm{Ag}$ alloys with single-phase structure.

Previous studies have proved that solid solution treatment decreases the biodegradation rate of $\mathrm{Mg}-\mathrm{Zn}$ system alloys by decomposing the secondary phase particles and reducing the micro-galvanic corrosion [31-34]. According to the $\mathrm{Mg}-\mathrm{Zn}$ and $\mathrm{Mg}-\mathrm{Ag}$ binary equilibrium phase 
diagram, the solid solubility of $\mathrm{Zn}, \mathrm{Ag}$ in magnesium is 6.2 wt $\%$ at $340{ }^{\circ} \mathrm{C}$ and $15.02 \mathrm{wt} \%$ at $472{ }^{\circ} \mathrm{C}$, respectively [35]. Recently, Wang et al. [36] reported $\mathrm{Mg}-\mathrm{Zn}-\mathrm{Ag}$ ternary phase diagram and revealed that both $\mathrm{Zn}$ and $\mathrm{Ag}$ had a certain amount of solid solubility in $\mathrm{Mg}$ matrix. It indicates that single-phase structure $\mathrm{Mg}-\mathrm{Zn}-\mathrm{Ag}$ alloys can be obtained by solid solution treatment. In the present study, $\mathrm{Mg}-3 \mathrm{Zn}-x \mathrm{Ag}$ (wt $\%, x=0.2,0.5$ and 0.8 ) alloys were prepared by the backward extrusion technology at elevated temperature in order to develop a single-phase $\mathrm{Mg}-\mathrm{Zn}-\mathrm{Ag}$ alloys. The influences of Ag concentration on microstructures, mechanical properties and corrosion behavior of the extruded $\mathrm{Mg}-3 \mathrm{Zn}-\mathrm{Ag}$ alloys are presented.

\section{Experimental Procedures}

\subsection{Sample Preparation}

The $\mathrm{Mg}-3 \mathrm{Zn}-x \mathrm{Ag}$ (where $x=0.2,0.5$ and $0.8 \mathrm{wt} \%$ ) alloy ingots were prepared by induction melting pure constituent elements $\mathrm{Mg}$ (99.99\%), Zn (99.95\%) and $\mathrm{Ag}$ (99.95\%) under a mixture of $\mathrm{N}_{2}$ and $0.2 \% \quad \mathrm{SF}_{6}$ atmosphere in a graphite crucible and casted into a steel mold $(\Phi 60 \mathrm{~mm} \times 180 \mathrm{~mm})$, which was preheated to $250{ }^{\circ} \mathrm{C}$. The casting ingots were homogenized at $320^{\circ} \mathrm{C}$ for $2 \mathrm{~h}$ and solution treated at $400{ }^{\circ} \mathrm{C}$ for $8 \mathrm{~h}$ with the protection of graphite powders and machined into $\Phi 48 \mathrm{~mm}$ cylinders. Subsequently, the billets were indirectly extruded into $\Phi 6 \mathrm{~mm}$ bars with ram speed of $200 \mathrm{~mm} / \mathrm{min}$ at $340{ }^{\circ} \mathrm{C}$ in order to obtain the single-phase microstructure. The nominal and measured compositions of samples are listed in Table 1 .

\subsection{Crystal Structure and Microstructure Characterization}

Microstructural investigations were performed by scanning electron microscopy (SEM, JEOLJSM-7001F) and transmission electron microscopy (TEM, JEOL JEM-2100F) equipped with energy-dispersive X-ray spectrometry. Electron backscatter diffraction (EBSD) was applied to

Table 1 Composition of $\mathrm{Mg}-\mathrm{Zn}(-\mathrm{Ag})$ alloys measured by ICP-AES (balance magnesium)

\begin{tabular}{llll}
\hline Alloy & $\mathrm{Mg}(\mathrm{wt} \%)$ & $\mathrm{Zn}(\mathrm{wt} \%)$ & $\mathrm{Ag}(\mathrm{wt} \%)$ \\
\hline Mg-3Zn & 97.20 & 2.80 & 0 \\
$\mathrm{Mg}-3 \mathrm{Zn}-0.2 \mathrm{Ag}$ & 96.97 & 2.83 & 0.20 \\
$\mathrm{Mg}-3 \mathrm{Zn}-0.5 \mathrm{Ag}$ & 96.61 & 2.88 & 0.51 \\
$\mathrm{Mg}-3 \mathrm{Zn}-0.8 \mathrm{Ag}$ & 96.34 & 2.88 & 0.78 \\
\hline
\end{tabular}

reveal microstructure details and local crystallographic orientation. For the microstructural analyses, the samples were mechanically polished and electrolytically polished with a solution of $10 \mathrm{~mL}$ perchloric acid $\left(\mathrm{HClO}_{4}\right)$ and $90 \mathrm{~mL}$ ethanol $\left(\mathrm{C}_{2} \mathrm{H}_{5} \mathrm{OH}\right)$ for $120 \mathrm{~s}$. The specimens for TEM observation were ground to $30 \mu \mathrm{m}$ and further thinned with ion milling. The crystal structures were determined by X-ray diffractometer (Rigaku SmartLab) with $\mathrm{Cu}$ $K \alpha$ radiation at $40 \mathrm{kV}$ and $200 \mathrm{~mA}$.

\subsection{Mechanical Properties}

Mechanical testing samples with a diameter of $5 \mathrm{~mm}$ and a gauge length of $30 \mathrm{~mm}$ were cut from the extruded bars for tensile test. The tensile tests were conducted on a Shimadzu AG-X100kN electromechanical universal testing machine at a displacement rate of $1.5 \mathrm{~mm} / \mathrm{min}$ at ambient temperature. The tensile axis was parallel to the extrusion direction, and at least three samples were examined for each testing material.

\subsection{Electrochemical Corrosion Properties}

Cylindrical specimens with a diameter of $6 \mathrm{~mm}$ were molded in epoxy resin for electrochemical tests. The test was conducted at $37{ }^{\circ} \mathrm{C}$ in an open air glass cell containing $200 \mathrm{~mL} \mathrm{SBF}$ (simulated body fluid) solution at $\mathrm{pH} 7.40$ by using VersaSTAT-3 potentiostat/galvanostat (Princeton Applied Research), and the chemical compositions of SBF solution are given in Table 2 [37]. A three-electrode cell was used for potentiodynamic polarization tests, where the reference electrode was saturated calomel electrode (SCE), the counter electrode was platinum electrode $(\mathrm{Pt})$ and the specimen was working electrode (WE). All experiments were carried out at a constant scan rate of $1 \mathrm{mV} / \mathrm{s}$ initiated at $300 \mathrm{mV}$ below the open-circuit potential to $400 \mathrm{mV}$ above the open-circuit potential.

The polarization curves were used to measure the corrosion current density $\left(i_{\text {corr }}: \mathrm{mA} / \mathrm{cm}^{2}\right)$ at corrosion potential $\left(E_{\text {corr }}\right)$ by Tafel extrapolation of the cathodic branch. And $i_{\text {corr }}$ is related to the average corrosion rate using Eq. (1) [38]

$P_{i}=22.85 i_{\text {corr }}$.

\subsection{Immersion Corrosion Behavior}

To investigate the corrosion behavior in vitro conditions, $\Phi 6 \mathrm{~mm} \times 3 \mathrm{~mm}$ samples were cut and mechanically ground. Afterward the ground samples were washed ultrasonically with ethanol and then dried with a warm airflow for immersion test. The samples were weighed before and after immersion in thermostatic water bath at 
Table 2 Chemical composition of SBF solution $(\mathrm{g} / \mathrm{L})$ used in these experiments

\begin{tabular}{llllllllll}
\hline $\mathrm{NaCl}$ & $\mathrm{NaHCO}_{3}$ & $\mathrm{KCl}$ & $\mathrm{K}_{2} \mathrm{HPO}_{4} \cdot 3 \mathrm{H}_{2} \mathrm{O}$ & $\mathrm{MgCl}_{2} \cdot 6 \mathrm{H}_{2} \mathrm{O}$ & $c(\mathrm{HCl})=1 \mathrm{~mol} / \mathrm{L}(\mathrm{mL})$ & $\mathrm{CaCl}_{2}$ & $\mathrm{NaSO}_{4}$ & $\mathrm{TRIS}$ & $c(\mathrm{HCl})=1 \mathrm{~mol} / \mathrm{L}(\mathrm{mL})$ \\
\hline 8.035 & 0.355 & 0.225 & 0.231 & 0.311 & 39 & 0.292 & 0.072 & 6.118 & $0-5$
\end{tabular}

$37{ }^{\circ} \mathrm{C}$ using a balance with a precision scale resolution of $0.1 \mathrm{mg}$. Each sample was suspended with nylon strings and completely immersed in $30 \mathrm{~mL}$ SBF solution with $\mathrm{pH}$ value 7.40. Samples were removed from SBF after immersion of 1, 2, 4, 8 and 14 days and then cleaned with $200 \mathrm{~g} / \mathrm{L}$ of chromic acid $\left(\mathrm{CrO}_{3}\right)$ solution in the ultrasonic cleaning machine to remove the corrosion products. The in vitro corrosion rate $\left(P_{w}\right)$ was calculated by the following equation according to the weight loss:

$P_{w}=(8.76 \times W) /(A \times T \times \rho)$,

where $W$ is the weight loss after immersion $(\mathrm{g}), A$ is the sample area exposed to solution $\left(\mathrm{m}^{2}\right), T$ is the exposure time (h) and $\rho$ is the density of the material $\left(\mathrm{g} \mathrm{cm}^{-3}\right)$. The weight loss tests were conducted three times in different days, using a new sample and a new solution.

\section{Results and Discussion}

\subsection{Crystal Structure}

Figure 1 presents the X-ray diffraction (XRD) results for the extruded $\mathrm{Mg}-\mathrm{Zn}(-\mathrm{Ag})$ alloys. As shown in Fig. 1, only the diffraction peaks of $\alpha-\mathrm{Mg}$ can be observed in all the four alloys, which suggests that introduced $\mathrm{Ag}$ element is solute in $\alpha-\mathrm{Mg}$ matrix and the extruded $\mathrm{Mg}-\mathrm{Zn}(-\mathrm{Ag})$ alloys are of single-phase structure as expected. The lattice parameters of extruded $\mathrm{Mg}-\mathrm{Zn}-\mathrm{Ag}$ alloys are summarized in Table 3. It can be seen that the lattice parameter $a$ slightly increases and $c$ decreases with the addition of

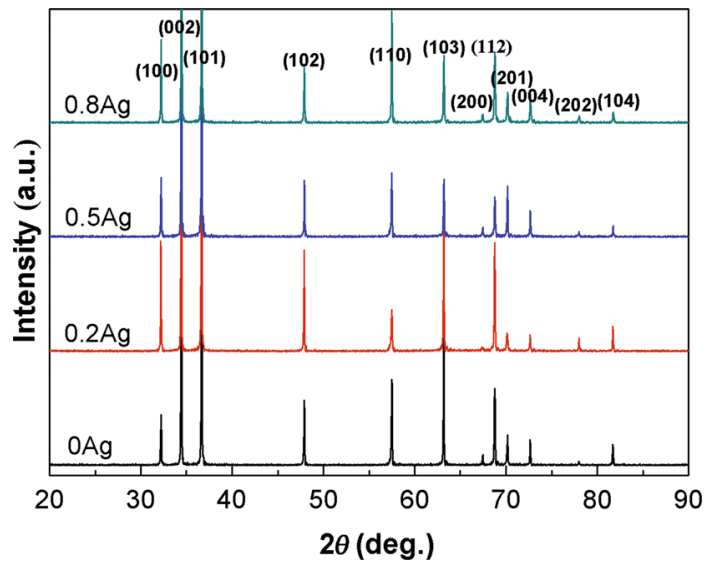

Fig. 1 XRD patterns of as-extruded $\mathrm{Mg}-\mathrm{Zn}(-\mathrm{Ag})$ alloys
Table 3 Lattice parameters of extruded $\mathrm{Mg}-\mathrm{Zn}(-\mathrm{Ag})$ alloys

\begin{tabular}{llll}
\hline Alloys & $a(\mathrm{~nm})$ & $c(\mathrm{~nm})$ & $c / a$ \\
\hline $\mathrm{Mg}-3 \mathrm{Zn}$ & 3.2034 & 5.2014 & 1.6236 \\
$\mathrm{Mg}-3 \mathrm{Zn}-0.2 \mathrm{Ag}$ & 3.2047 & 5.2008 & 1.6229 \\
$\mathrm{Mg}-3 \mathrm{Zn}-0.5 \mathrm{Ag}$ & 3.2036 & 5.2004 & 1.6232 \\
$\mathrm{Mg}-3 \mathrm{Zn}-0.8 \mathrm{Ag}$ & 3.2031 & 5.2006 & 1.6236 \\
\hline
\end{tabular}

$0.2 \% \mathrm{Ag}$ into the $\mathrm{Mg}-3 \mathrm{Zn}$ alloy, which results in the decrease in $c / a$ ratio of $\mathrm{Mg}-3 \mathrm{Zn}$ alloys, whereas when the Ag content is larger than $0.2 \%$, both the lattice parameters $a$ and $c$ of extruded $\mathrm{Mg}-\mathrm{Zn}-\mathrm{Ag}$ alloys decrease with the increasing $\mathrm{Ag}$ content. It indicates that the addition of $\mathrm{Ag}$ element to $\mathrm{Mg}-\mathrm{Zn}$ changes the lattice parameters by occupying the substitutional sites of the crystal lattice.

\subsection{Microstructure}

Figure $2 \mathrm{a}-\mathrm{d}$ shows the optical microstructures of $\mathrm{Mg}-\mathrm{Zn}(-$ $\mathrm{Ag}$ ) alloys after solid solution treatment. It can be observed that the grain sizes of $\mathrm{Mg}-\mathrm{Zn}-\mathrm{Ag}$ alloys are more than $200 \mu \mathrm{m}$ after solid solution treatment. Thus, the mechanical properties of solution-treated $\mathrm{Mg}-\mathrm{Zn}(-\mathrm{Ag})$ alloys are poor. After extrusion, $\mathrm{Mg}-\mathrm{Zn}(-\mathrm{Ag})$ alloys are composed of homogeneous equiaxed grains with perfect morphologies (Fig. 2a1-d1). It is suggested that the microstructures are of typical single-phase microstructure for all the alloys. The SEM-EDS mapping demonstrates that the $\mathrm{Zn}$ and $\mathrm{Ag}$ elements are distributed homogeneously in the $\mathrm{Mg}$ matrix without microscopic segregation and precipitation occurred during hot extrusion because of the high solubility and high extrusion temperature as shown in Fig. 3, which indicates that the $\mathrm{Zn}$ and $\mathrm{Ag}$ elements are fully solute in the $\mathrm{Mg}$ matrix.

The average grain sizes of extruded $\mathrm{Mg}-\mathrm{Zn}(-\mathrm{Ag})$ alloys were determined according to the standard test method (ASTM E112-96), as shown in Fig. 4. All the extruded alloys appear to be an approximate normal distribution with a single peak despite the different peak values, which indicates a slight difference in the average grain size for four alloys. The $\mathrm{Mg}-3 \mathrm{Zn}-0.2 \mathrm{Ag}$ alloy possesses the smallest grain size $(\sim 33.3 \mu \mathrm{m})$, as shown in Fig. $4 \mathrm{~b}$. The average grain size of the $\mathrm{Mg}-3 \mathrm{Zn}, \mathrm{Mg}-3 \mathrm{Zn}-0.5 \mathrm{Ag}$ and $\mathrm{Mg}-3 \mathrm{Zn}-0.8 \mathrm{Ag}$ alloy is about 35.6, 38.6 and $41.3 \mu \mathrm{m}$, 

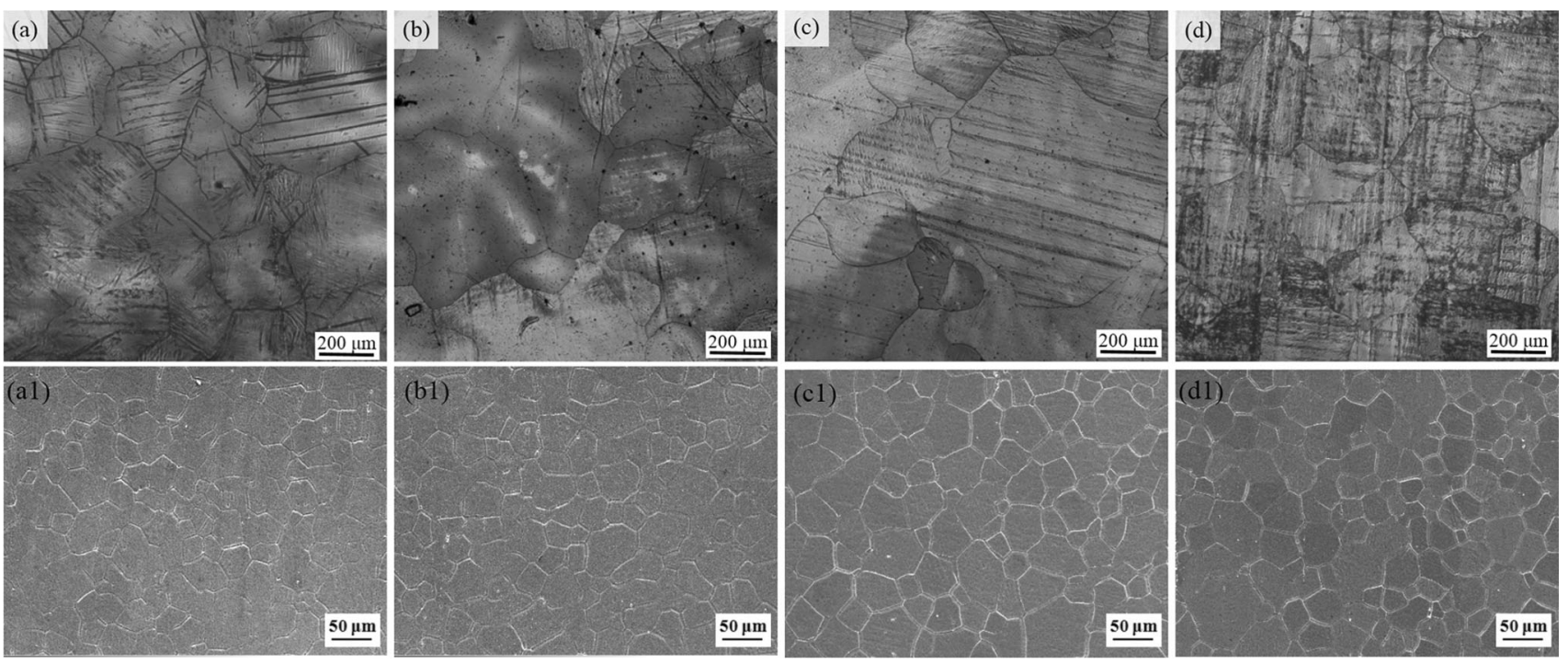

Fig. 2 Optical micrographs of solid solute treatment $\mathrm{Mg}-\mathrm{Zn}(-\mathrm{Ag})$ alloys and SEM-BSE images of as-extruded $\mathrm{Mg}-\mathrm{Zn}(-\mathrm{Ag})$ alloys a, a1 Mg$3 Z n$, b, b1 Mg-3Zn-0.2Ag, c, c1 Mg-3Zn-0.5Ag, d, d1 Mg-3Zn-0.8Ag
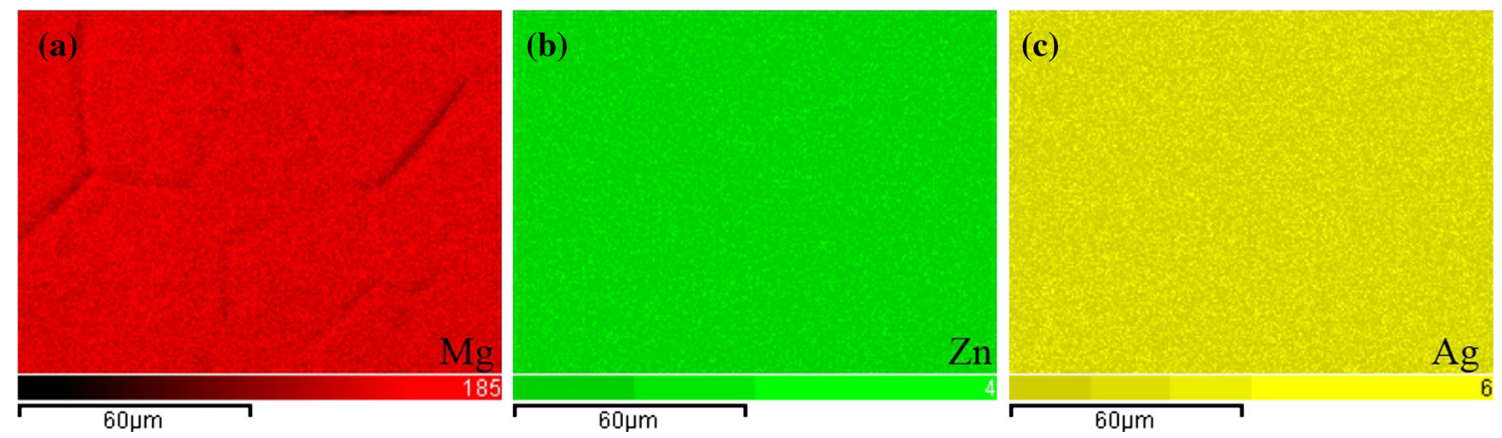

Fig. 3 SEM-EDS mapping of all the extruded $\mathrm{Mg}-\mathrm{Zn}-\mathrm{Ag}$ alloys: a $\mathrm{Mg}, \mathbf{b} \mathrm{Zn}, \mathbf{c} \mathrm{Ag}$

respectively, as shown in Fig. 4a, c, d, respectively. Regarding the microstructural heterogeneity, $\Delta d / d_{\mathrm{m}}$ is used to characterize relative grain size dispersions according to Ref. [39], where $d$ is the grain size, $d_{m}$ is the average grain size and $\Delta d=d_{\max }-d_{\min }$. It is easy to find the $\mathrm{Mg}-3 \mathrm{Zn}-$ $0.2 \mathrm{Ag}$ alloy has a more uniform grain size distribution.

EBSD technique was employed to investigate the detailed microstructure and local crystallographic orientation of extruded $\mathrm{Mg}-\mathrm{Zn}(-\mathrm{Ag})$ alloys. Figure 5 presents the inverse pole figure (IPF-Y) and band contrast mappings of the extruded $\mathrm{Mg}-\mathrm{Zn}(-\mathrm{Ag})$ alloys. As can be seen from Fig. 5a-d, all the microstructures are composed of homogeneous equiaxed grains with $\langle 010\rangle_{\mathrm{Mg}}$ and $\langle 120\rangle_{\mathrm{Mg}}$ direction parallel to the normal direction of sample surface. Twins are also observed in all the four alloys, as shown in Fig. 5a1-d1. Crystallographic calculation reveals that these twins are of the conventional tensile twin in magnesium alloys. The corresponding twinning system is $\{10 \overline{1} 2\}<1 \overline{2} 10>$. It can be clearly seen that the $\mathrm{Mg}-3 \mathrm{Zn}-$ $0.2 \mathrm{Ag}$ alloy possesses fewer twins than other alloys.
Figure 6 shows the TEM bright field images of extruded $\mathrm{Mg}-3 \mathrm{Zn}-0.2 \mathrm{Ag}$ and $\mathrm{Mg}-3 \mathrm{Zn}-0.8 \mathrm{Ag}$ alloys, where the electron beam is parallel to the $<1 \overline{2} 10>$ direction of $\alpha-\mathrm{Mg}$. As shown in Fig. 6a, c, no precipitation of second phase is observed in the two alloys, which is in good consistency with the SEM and XRD results, whereas twins and stacking faults in grain and twins are observed in Fig. 6. According to the SAED patterns in Fig. 6b, d, the twinning plane is of $\{10 \overline{1} 2\}$, which is marked with white arrows in Fig. 6b, whereas the stacking faults are along the $\{0002\}$ plane, which are marked with red arrows in Fig. 6b, d.

\subsection{Mechanical Properties}

Figure 7 shows the tensile stress-strain curves and the corresponding TYS, UTS as well as elongation of extruded $\mathrm{Mg}-\mathrm{Zn}(-\mathrm{Ag})$ alloys at room temperature. Firstly, there is almost no change in the TYS and UTS with the addition of $\mathrm{Ag}$ elements into $\mathrm{Mg}-3 \mathrm{Zn}$ alloys. As the microstructures shown, the Ag content not only affects the grain size but 

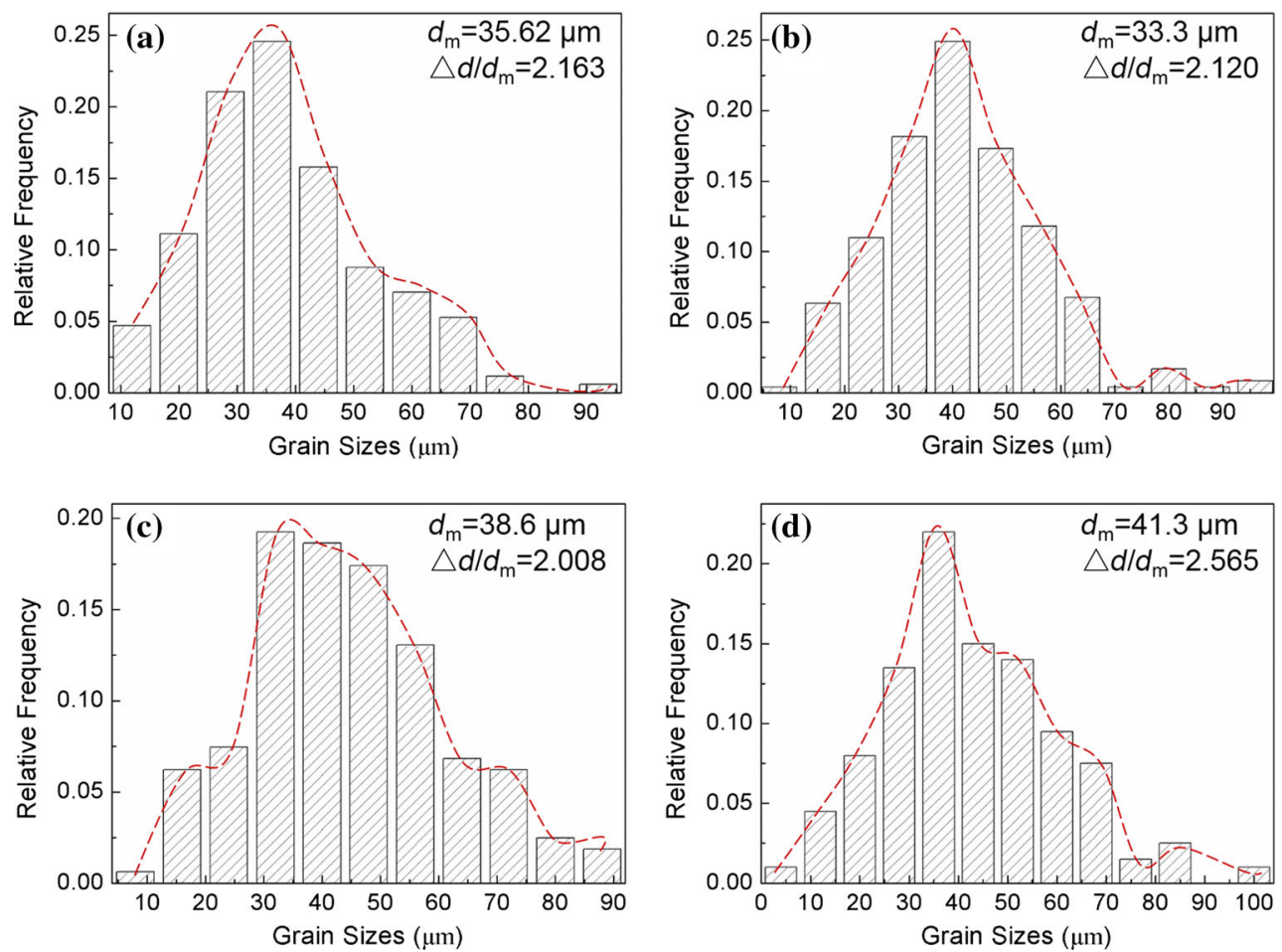

Fig. 4 Grain size distributions of the extruded $\mathrm{Mg}-\mathrm{Zn}(-\mathrm{Ag})$ alloys: a $\mathrm{Mg}-3 \mathrm{Zn}, \mathbf{b} \mathrm{Mg}-3 \mathrm{Zn}-0.2 \mathrm{Ag}, \mathbf{c} \mathrm{Mg}-3 \mathrm{Zn}-0.5 \mathrm{Ag}, \mathbf{d ~ M g}-3 \mathrm{Zn}-0.8 \mathrm{Ag}$
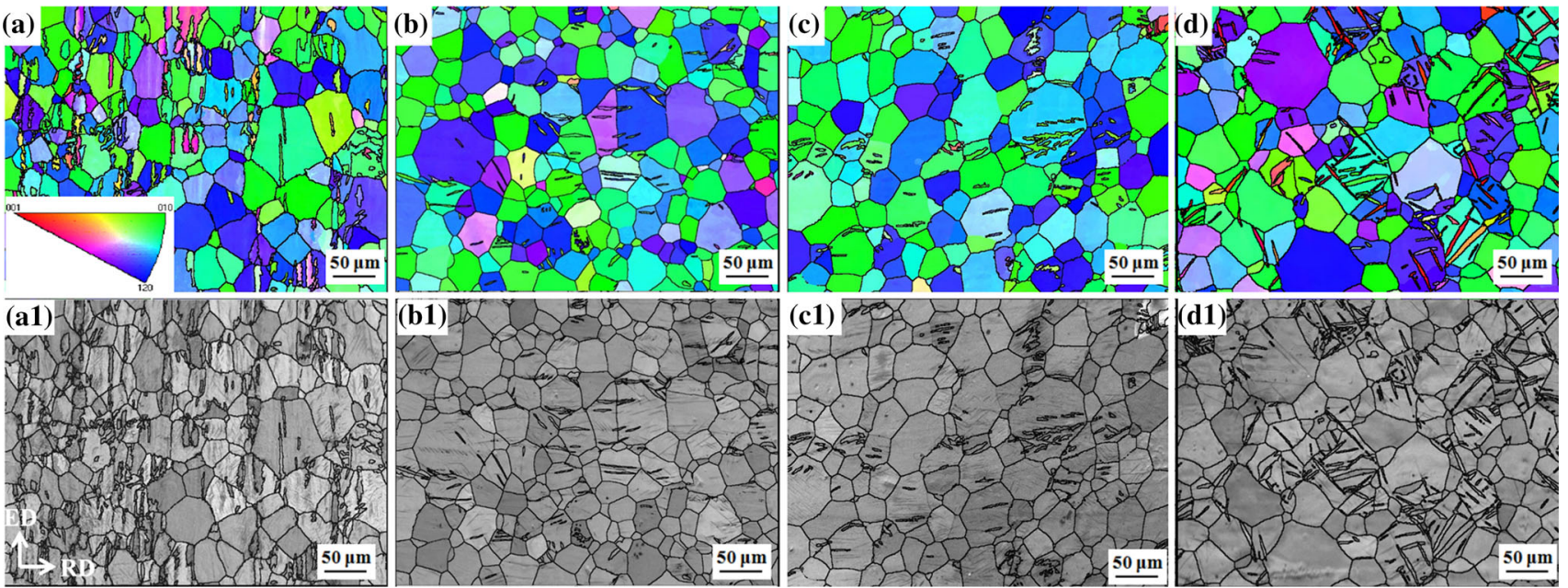

Fig. 5 EBSD inverse pole figure (IPF) map of as-extruded $\mathrm{Mg}-\mathrm{Zn}(-\mathrm{Ag})$ alloys: a, a1 $\mathrm{Mg}-3 \mathrm{Zn}, \mathbf{b}, \mathbf{b} \mathbf{1} \mathrm{Mg}-3 \mathrm{Zn}-0.2 \mathrm{Ag}, \mathbf{c}, \mathbf{c 1} \mathrm{Mg}-3 \mathrm{Zn}-0.5 \mathrm{Ag}, \mathbf{d}$, d1 $\mathrm{Mg}-3 \mathrm{Zn}-0.8 \mathrm{Ag}$

also influences the grain size distribution. It is evident that $\mathrm{Mg}-3 \mathrm{Zn}-0.8 \mathrm{Ag}$ alloy has the biggest grain size and grain size distribution. Even though its solid solution strengthening is greatest, the TYS and UTS of $\mathrm{Mg}-3 \mathrm{Zn}-0.8 \mathrm{Ag}$ alloy is almost the same with $\mathrm{Mg}-3 \mathrm{Zn}$ alloy. The elongation of extruded $\mathrm{Mg}-\mathrm{Zn}(-\mathrm{Ag})$ alloys increases tremendously from $12 \%$ to $19.8 \%$ with the addition of $0.2 \mathrm{wt} \%$ $\mathrm{Ag}$. Subsequently, it decreases to $15.8 \%$ and $9.9 \%$ for $\mathrm{Mg}-$ $3 \mathrm{Zn}-0.5 \mathrm{Ag}$ and $\mathrm{Mg}-3 \mathrm{Zn}-0.8 \mathrm{Ag}$, respectively. This may be related to the solution of a little Ag decreasing the $c / a$ ratio of Mg matrix, which activates non-basal slip systems and improves the room temperature plasticity of $\mathrm{Mg}-3 \mathrm{Zn}-$ $0.2 \mathrm{Ag}$ alloy [40-42]. Therefore, the mechanical properties of $\mathrm{Mg}-\mathrm{Zn}-\mathrm{Ag}$ alloys are related to solute atoms, grain sizes, dislocations and twinning. The TYS, UTS and elongation of $\mathrm{Mg}-3 \mathrm{Zn}-0.2 \mathrm{Ag}$ alloy reach up to 142 , $234 \mathrm{MPa}$ and $19.8 \%$, respectively, exhibiting the best combination of tensile strength and elongation in the present work. To fulfill the complex stress conditions of implants in physiological environment, a good balance 

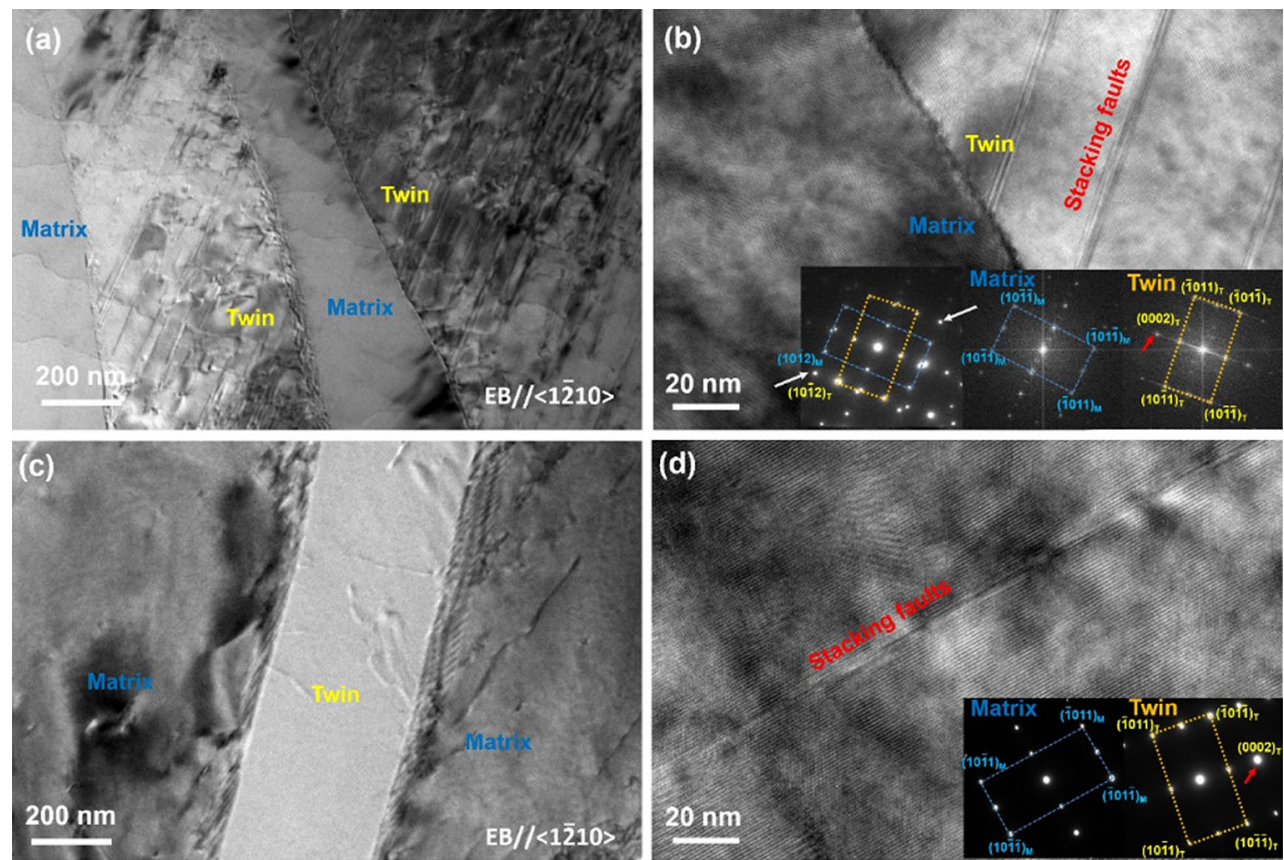

Fig. 6 TEM bright field micrographs of the as-extruded $\mathrm{Mg}-\mathrm{Zn}-\mathrm{Ag}$ alloys: a, b $\mathrm{Mg}-3 \mathrm{Zn}-0.2 \mathrm{Ag}, \mathbf{c}, \mathbf{d ~ M g}-3 \mathrm{Zn}-0.8 \mathrm{Ag}$
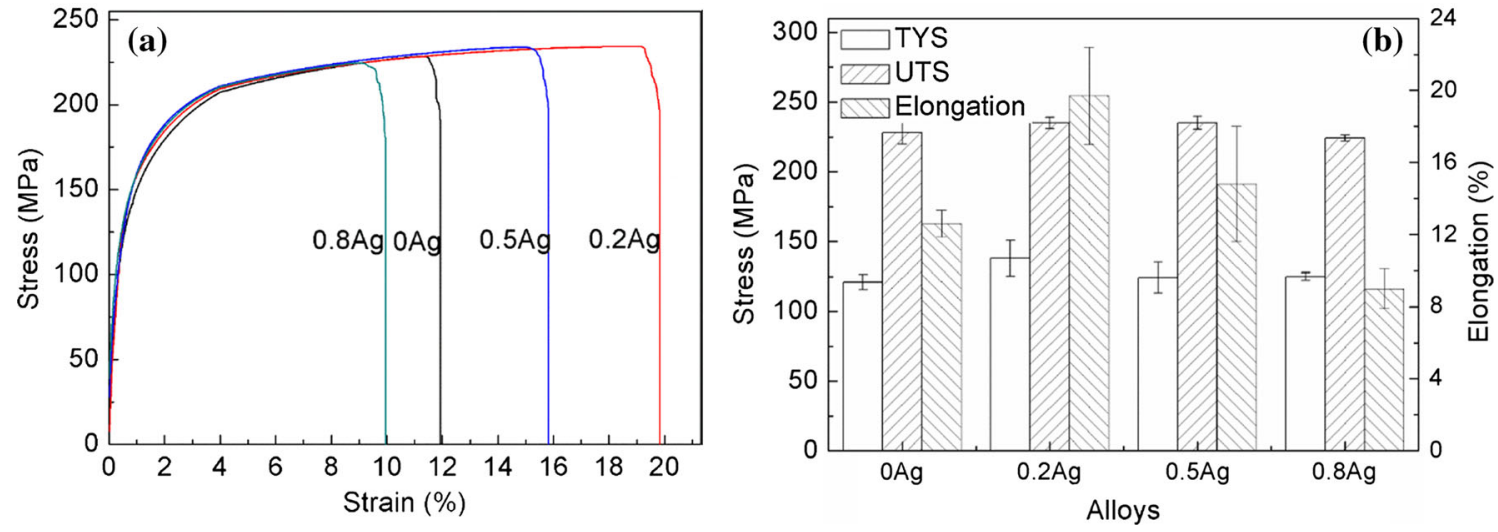

Fig. 7 Tensile stress-strain curves a and the corresponding yield strength, ultimate strength as well as elongation of extruded $\mathrm{Mg}-\mathrm{Zn}(-\mathrm{Ag})$ alloys $\mathbf{b}$. The load direction is parallel to extrusion direction

between strength and ductility is required, which indicates that the $\mathrm{Mg}-3 \mathrm{Zn}-0.2 \mathrm{Ag}$ alloy possesses great potential for implant application.

\subsection{Corrosion Behavior}

Figure 8 shows the potentiodynamic polarization curves of extruded $\mathrm{Mg}-\mathrm{Zn}(-\mathrm{Ag})$ alloys. The details of the corrosion parameters are listed in Table 4. It can be observed that the corrosion potential $\left(E_{\text {corr }}\right)$ become more positive with the increase in the $\mathrm{Ag}$ concentration in the $\mathrm{Mg}-3 \mathrm{Zn}$ alloys. By addition of $0.2 \mathrm{wt} \% \mathrm{Ag}$ into the binary $\mathrm{Mg}-3 \mathrm{Zn}$ alloy, the corrosion current density decreases from 60.534 to $33.627 \mu \mathrm{A} / \mathrm{cm}^{2}$, indicating that corrosion is kinetically more difficult for $\mathrm{Mg}-3 \mathrm{Zn}-0.2 \mathrm{Ag}$ alloy. However, the corrosion current increases to 68.938 and $101.594 \mu \mathrm{A} / \mathrm{cm}^{2}$ when introduction of 0.5 and $0.8 \mathrm{wt} \% \mathrm{Ag}$ to the $\mathrm{Mg}-3 \mathrm{Zn}$ alloy, respectively, which indicates the higher electrochemical activity and the poorer corrosion resistance compared with $\mathrm{Mg}-3 \mathrm{Zn}-0.2 \mathrm{Ag}$.

The polarization resistance $\left(R_{\mathrm{p}}\right)$ was calculated using the $i_{\text {corr }}, \beta_{c}$ and $\beta_{a}$ values from Eq. (3) [43], which is given as $R_{\mathrm{p}}=\frac{\beta_{a} \cdot \beta_{c}}{2.3 \cdot\left(\beta_{a}+\beta_{c}\right) \cdot i_{\text {corr }}}$.

As shown in Table $4, \mathrm{Mg}-3 \mathrm{Zn}-0.2 \mathrm{Ag}$ alloy has the highest $R_{\mathrm{p}}$ value, whereas $\mathrm{Mg}-3 \mathrm{Zn}-0.8 \mathrm{Ag}$ alloy has the lowest value. $\mathrm{Mg}-3 \mathrm{Zn}$ and $\mathrm{Mg}-3 \mathrm{Zn}-0.5 \mathrm{Ag}$ alloys have 


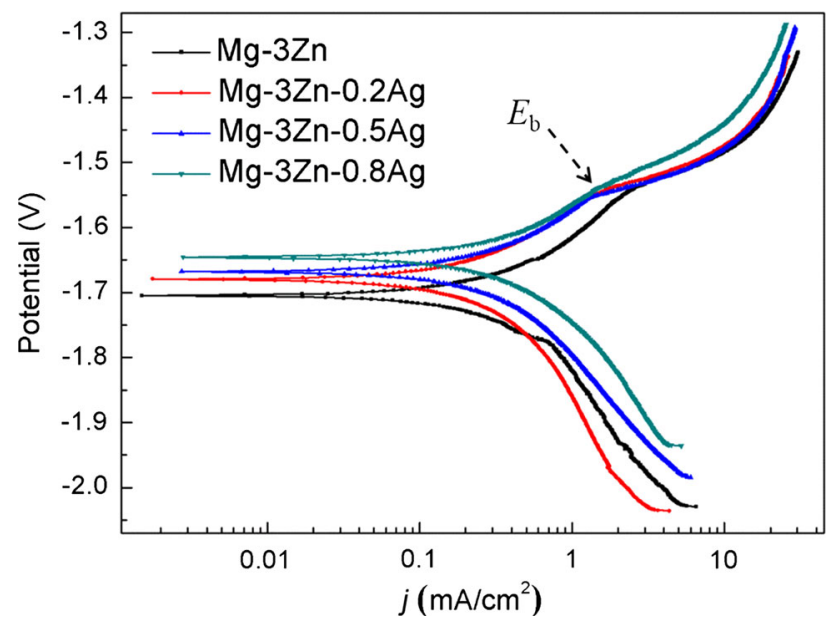

Fig. 8 Electrochemical polarization curves of $\mathrm{Mg}-\mathrm{Zn}(-\mathrm{Ag})$ alloys in SBF solution

intermediate $R_{\mathrm{p}}$ values. It is suggested that the corrosion layer on the $\mathrm{Mg}-3 \mathrm{Zn}-0.2 \mathrm{Ag}$ alloy is more protective and less susceptible to pitting corrosion than that of other samples.

Figure 9 shows the corrosion rate of the four $\mathrm{Mg}-\mathrm{Zn}$ ($\mathrm{Ag}$ ) alloys in SBF solution and XRD patterns of the corrosion products after 14 days of immersion. As can be seen in Fig. 9a, all four alloys present a high corrosion rate at first and then the rate decreases gradually with further immersion time due to the formation of the protective layer. Within the whole immersion test, $\mathrm{Mg}-3 \mathrm{Zn}-0.2 \mathrm{Ag}$ alloy shows the lowest corrosion rate of $3.2 \mathrm{~mm} / \mathrm{year}$, while $\mathrm{Mg}-3 \mathrm{Zn}-0.8 \mathrm{Ag}$ alloy shows the highest corrosion rate of $4.8 \mathrm{~mm} / \mathrm{year}$. The immersion results reveal that $\mathrm{Mg}-3 \mathrm{Zn}-0.2 \mathrm{Ag}$ alloy has the best corrosion resistance owing to its uniform microstructures, which is in agreement with the results of electrochemical test. The difference between $P_{i}$ and $P_{w}$ is due to the chemical erosion, electrochemical corrosion and washing process of corrosion products. The EDS (not given) and XRD results (Fig. 9b) suggest the existence of biocompatible $\mathrm{Mg}(\mathrm{OH})_{2}$ and HA on the surface of the corroded alloys, which act as corrosion barriers to decelerate corrosion.

To investigate the degradation behavior, macro-surface morphologies after removing the corrosion products of the specimens immersed for different times in SBF solution were observed, as shown in Fig. 10. Many corrosion pits can be seen on the surface of different $\mathrm{Mg}-\mathrm{Zn}(-\mathrm{Ag})$ alloys, whose sizes and depths are found to increase with the pass of immersion time. The results suggest that there are pitting corrosion behaviors for four alloys. After immersion for 4 days, many corrosion pits are presented as opposed to almost intact original surface. After 8 days, all the $\mathrm{Mg}-$ $\mathrm{Zn}(-\mathrm{Ag})$ alloys exhibit pitting corrosion and erosion on the

Table 4 Electrochemical parameters of $\mathrm{Mg}-\mathrm{Zn}(-\mathrm{Ag})$ alloys from the polarization test

\begin{tabular}{llllllll}
\hline Alloy & $\begin{array}{l}\text { Corrosion } \\
\text { potential, } E_{\text {corr }} \\
(V \text { vs. SCE })\end{array}$ & $\begin{array}{l}\text { Pitting } \\
\text { potential, } E_{\mathrm{b}} \\
(V \text { vs.SCE })\end{array}$ & $\begin{array}{l}\text { Current } \\
\text { density, } i_{\text {corr }} \\
(\mu \mathrm{A} / \mathrm{cm})\end{array}$ & $\begin{array}{l}\text { Cathodic slope, } \beta_{c} \\
(\mathrm{mV} / \text { decade }) \\
\text { versus SCE }\end{array}$ & $\begin{array}{l}\text { Anodic slope, } \beta a \\
(\mathrm{mV} / \text { decade }) \\
\text { versus SCE }\end{array}$ & $\begin{array}{l}\text { Polarization } \\
\text { resistance, } R_{\mathrm{p}} \\
\left(\mathrm{k} \Omega \mathrm{cm}^{2}\right)\end{array}$ & $\begin{array}{l}\text { Corrosion } \\
\text { rate, } P_{i} \\
(\mathrm{~mm} / \mathrm{year})\end{array}$ \\
\hline $\mathrm{Mg}-3 \mathrm{Zn}$ & -1.704 & -1.549 & 60.534 & 135.142 & 106.784 & 0.43 & 1.4 \\
$\mathrm{Mg}-3 Z n-0.2 \mathrm{Ag}$ & -1.679 & -1.548 & 33.627 & 104.598 & 68.322 & 0.54 & 0.8 \\
$\mathrm{Mg}-3 Z n-0.5 \mathrm{Ag}$ & -1.667 & -1.546 & 68.938 & 181.715 & 124.388 & 0.45 & 0.35 \\
$\mathrm{Mg}-3 \mathrm{Zn}-0.8 \mathrm{Ag}$ & -1.645 & -1.541 & 101.594 & 202.528 & 138.116 & 2.3 \\
\hline
\end{tabular}
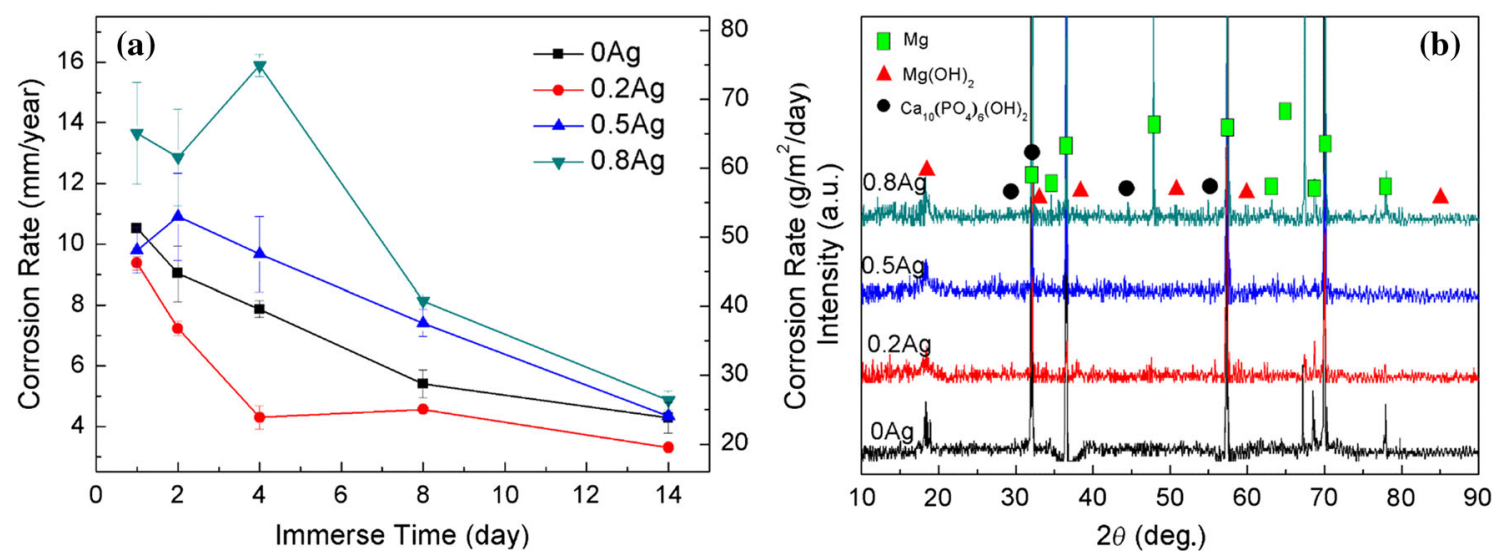

Fig. 9 a Corrosion rate of $\mathrm{Mg}-\mathrm{Zn}(-\mathrm{Ag})$ alloys after immersion in SBF solution for various times, $\mathbf{b}$ X-ray diffraction patterns of the corrosion products after immersion for 14 days 


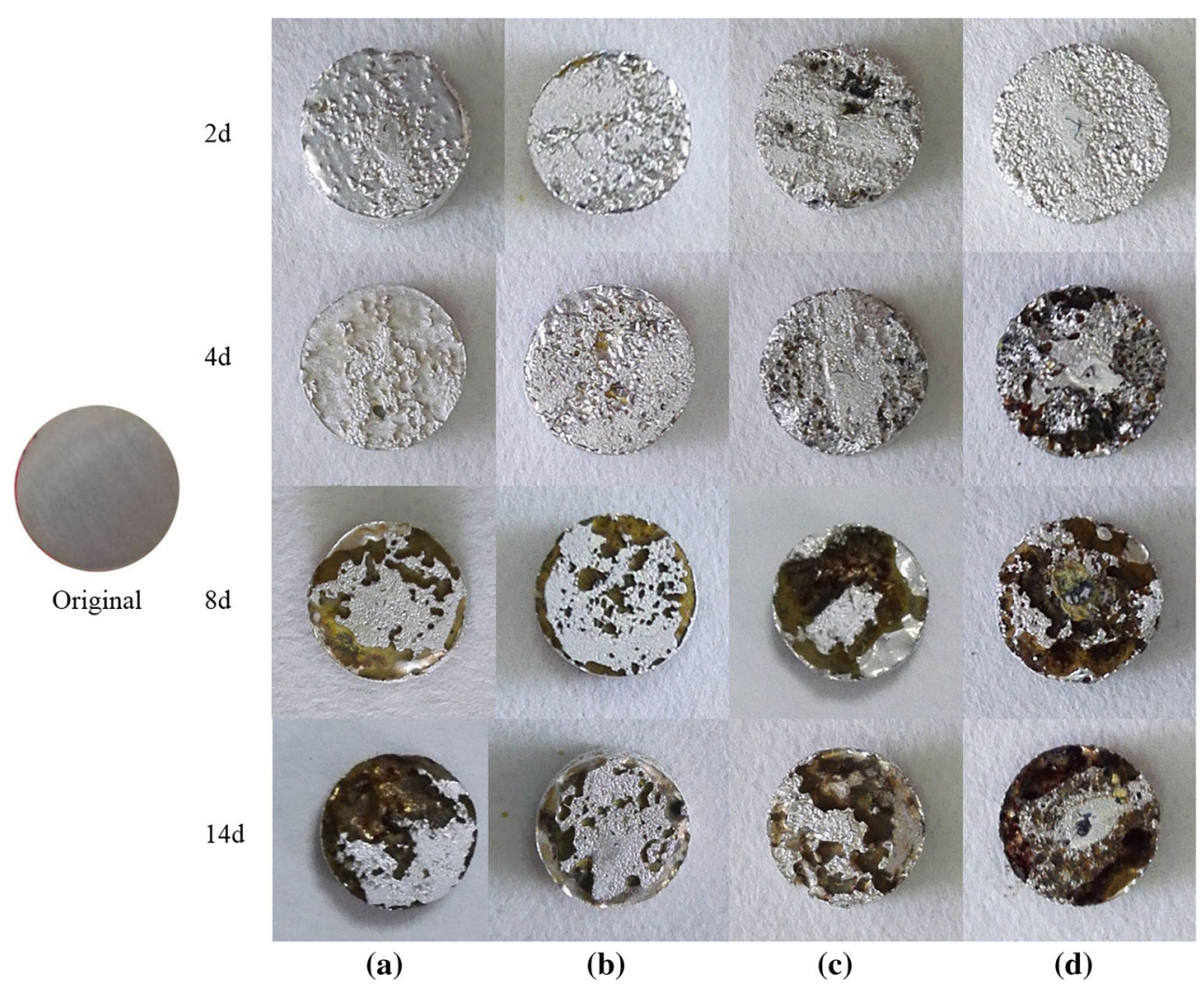

Fig. 10 Macro-morphologies of the corroded surfaces of $\mathrm{Mg}-\mathrm{Zn}(-\mathrm{Ag})$ alloys after immersion in SBF solution. a Mg-3Zn, b Mg-3Zn-0.2Ag, c Mg-3Zn-0.5Ag, d Mg-3Zn-0.8Ag

$\mathrm{Mg}-3 \mathrm{Zn}-0.8 \mathrm{Ag}$ alloy continues to be more substantial compared with its counterparts, indicating that there is more significant corrosion with increasing amount of silver content. The above observations are consistent with the results in potentiodynamic polarization tests.

As mentioned above, the extruded $\mathrm{Mg}-3 \mathrm{Zn}(-\mathrm{Ag})$ alloys with single-phase structure were fabricated by solid solution treatment. SEM and TEM results confirmed that there is no precipitation of secondary phase in the microstructure, and only homogeneous grains within twins and stacking faults can be observed in the microstructure. Therefore, the corrosion behavior of extruded $\mathrm{Mg}-\mathrm{Zn}$ ($\mathrm{Ag}$ ) alloys is related to grain size and amount of twins. Grain refinement will induce more grain boundaries and the redistribution of impurities on the grain boundaries, which results in uniform cathodic sites throughout the $\mathrm{Mg}-$ $\mathrm{Zn}(-\mathrm{Ag})$ alloy structure for cathodic reaction and improvement in corrosion resistance [44-46]. Moreover, Ralston et al. [47] and Gollapudi [48] showed that the corrosion rate was proportional to the reciprocal square root of grain size: $i_{\text {corr }}=a+b d^{-1 / 2}$, and $b$ is a positive value in a non-passivating environment when the grain sizes are in the range of $2-100 \mu \mathrm{m}$. Thus, $\mathrm{Mg}-3 \mathrm{Zn}-0.2 \mathrm{Ag}$ alloy with fine grains exhibits the lowest corrosion rate among all the extruded $\mathrm{Mg}-3 \mathrm{Zn}-\mathrm{Ag}$ alloys. Meanwhile, the corrosion behavior is sensitive to the crystallographic defects, such as twinning, dislocation and stacking faults. In terms of literature, the existence of twins will accelerate corrosion process due to the accelerated anodic dissolution in the vicinity of dislocations [43, 44, 49]. Thus, $\mathrm{Mg}-3 \mathrm{Zn}$ $0.2 \mathrm{Ag}$ alloy with the least twins in microstructure achieves the best corrosion behavior, which shows lower corrosion rate than those of $\mathrm{Mg}-1 \mathrm{Zn}-0.2 \mathrm{Ag}$ and $\mathrm{Mg}-1 \mathrm{Zn}-0.8 \mathrm{Ag}$ alloy with secondary phase particles [22].

\section{Conclusions}

The present work proposed the systemically investigation on the microstructure, mechanical properties and corrosion behavior of extruded $\mathrm{Mg}-3 \mathrm{Zn}(-\mathrm{Ag})$ alloys with singlephase structure. The following conclusions can be drawn:

1. The extruded $\mathrm{Mg}-3 \mathrm{Zn}(-\mathrm{Ag})$ alloys are of single-phase structure. The equiaxed grain size is about $30-50 \mu \mathrm{m}$, which indicates the occurrence of recrystallization during extrusion. Both the grain size and amount of twins show a trend of slight decrease and then increase with the concentration of $\mathrm{Ag}$ alloying element. 
2. As compared with the $\mathrm{Mg}-3 \mathrm{Zn}$ alloy, there was almost no increase in the yield strength and ultimate strength for Ag-containing alloys, while the elongation increased at first and then decreased with increment of $\mathrm{Ag}$ into $\mathrm{Mg}-3 \mathrm{Zn}$ alloy. The TYS, UTS and elongation of $\mathrm{Mg}-3 \mathrm{Zn}-0.2 \mathrm{Ag}$ alloys reached up to $142,234 \mathrm{MPa}$ and $19.8 \%$, which is the best mechanical performance of $\mathrm{Mg}-\mathrm{Zn}(-\mathrm{Ag})$ alloys in the present work.

3. The extruded $\mathrm{Mg}-3 \mathrm{Zn}-0.2 \mathrm{Ag}$ alloy also possesses the best corrosion behavior, and the corresponding corrosion rate is about $3.2 \mathrm{~mm} /$ year in immersion test. SEM and XRD results reveal that the corrosion products are composed of $\mathrm{Mg}(\mathrm{OH})_{2}$ and $\mathrm{HA}$ after the $\mathrm{Mg}-\mathrm{Zn}(-\mathrm{Ag})$ alloys immersed in the SBF for 14 days.

Acknowledgements This work was supported by the National Natural Science Foundation of China (Nos. 51371046 and 51525101), the National Key Research and Development Program of China (No. 2016YFB0701202) and the Fundamental Research Funds of the Central Universities (No. N141008001).

\section{References}

[1] B. Heublein, R. Rohde, V. Kaese, M. Niemeyer, W. Hartung, A. Haverich, Heart 89, 651 (2003)

[2] A. Chaya, S. Yoshizawa, K. Verdelis, N. Myers, B.J. Costello, D.T. Chou, S. Pal, S. Maiti, P.N. Kumta, C. Sfeir, Acta Biomater. 18, 262 (2015)

[3] Y.J. Chen, Z.G. Xu, C. Smith, J. Sankar, Acta Biomater. 10, 4561 (2014)

[4] J.M. Seitz, M. Durisin, J. Goldman, J.W. Drelich, Adv. Healthc. Mater. 4, 1915 (2015)

[5] P. Wan, L.L. Tan, K. Yang, J. Mater. Sci. Technol. 32, 827 (2016)

[6] H. Tapiero, K.D. Tew, Biomed. Pharmacother. 57, 399 (2003)

[7] Y.H. He, H.R. Tao, Y. Zhang, S.X. Zhang, C.L. Zhang, J.N. Li, B.L. Zhang, Y. Song, X.N. Zhang, Chin. Sci. Bull. 54, 484 (2009)

[8] Y. Yan, H.W. Cao, Y.J. Kang, K. Yu, T. Xiao, J. Luo, Y.W. Deng, H.J. Fang, H.Q. Xiong, D.L. Dai, J. Alloys Compd. 693, 1277 (2017)

[9] Y. Wu, N. Li, Y. Cheng, Y. Zheng, Y. Han, J. Mater. Sci. Technol. 29, 545 (2013)

[10] Z. Zhen, T.F. Xi, Y.F. Zheng, L. Li, L. Li, J. Mater. Sci. Technol. 30, 675 (2014)

[11] R.Q. Hou, C.Q. Ye, C.D. Chen, S.G. Dong, M.Q. Lv, S. Zhang, J.S. Pan, G.L. Song, C.J. Lin, Acta Metall. Sin. (Engl. Lett.) 29, $46(2016)$

[12] T. Li, H.L. Zhang, H. He, X.T. Wang, Mater. Corros. 66, 7 (2015)

[13] T. Li, H.L. Zhang, Y. He, N. Wen, X.T. Wang, J. Mater. Sci. Technol. 31, 744 (2015)

[14] Y.Z. Du, X.G. Qiao, M.Y. Zheng, K. Wu, S.W. Xu, Mater. Des. 85, 549 (2015)

[15] L.D. Hou, Z. Li, H. Zhao, Y. Pan, S. Pavlinich, X.W. Liu, X.L. Liu, Y.F. Zheng, L. Li, J. Mater. Sci. Technol. 32, 874 (2016)
[16] X. Zhang, G. Yuan, L. Mao, J. Niu, W. Ding, Mater. Lett. 66, 209 (2012)

[17] X.M. Zong, D. Wang, W. Liu, K.B. Nie, Acta Metall. Sin. (Engl. Lett.) 29, 32 (2016)

[18] H. Ibrahim, A.D. Klarner, B. Poorganji, D. Dean, A.A. Luo, M. Elahinia, J. Mech. Behav. Biomed. 69, 203 (2017)

[19] J. Luo, H. Yan, N. Zheng, R.S. Chen, Acta Metall. Sin. (Engl. Lett.) 29, 205 (2016)

[20] D.H. Cho, B.W. Lee, J.Y. Park, K.M. Cho, I.M. Park, J. Alloys Compd. 695, 1166 (2017)

[21] Y.L. Zhou, Y.C. Li, D.M. Luo, Y.F. Ding, P. Hodgson, Mater. Sci. Eng. C 49, 93 (2015)

[22] Q.M. Peng, K. Li, Z.S. Han, E.D. Wang, Z.G. Xu, R.P. Liu, Y.J. Tian, J. Biomed. Mater. Res. A 101, 1898 (2013)

[23] G. Ben-Hamu, D. Elizer, A. Kaya, Y.G. Na, K.S. Shin, Mater. Sci. Eng. A 435-436, 579 (2006)

[24] D.H. Cho, J.H. Nam, B.W. Lee, J.Y. Park, H.J. Shin, I.K. Park, Korean J. Met. Mater. 53, 220 (2015)

[25] S. Shao, Y. Liu, C.S. Xu, Y.X. Xu, B. Wu, X.S. Zeng, X.F. Liu, X.J. Yang, Acta Metall. Sin. (Engl. Lett.) 28, 7 (2015)

[26] J.L. Domingo, Neurotoxicol. Teratol. 17, 515 (1995)

[27] T.P. Flaten, Brain Res. Bull. 55, 187 (2001)

[28] S. Silver, L.T. Phung, G. Silver, Ind. Microbiol. Biotechnol. 33, 627 (2006)

[29] L.B. Tong, Q.X. Zhang, Z.H. Jiang, J.B. Zhang, J. Meng, L.R. Cheng, H.J. Zhang, J. Mech. Behav. Biomed. 62, 57 (2016)

[30] Y. Xin, T. Hu, P.K. Chu, Acta Biomater. 7, 1452 (2011)

[31] S.X. Zhang, J.N. Li, Y. Song, C.L. Zhao, C.Y. Xie, X.N. Zhang, Adv. Eng. Mater. 12, 170 (2010)

[32] H.R. Bakhsheshi-Rad, E. Hamzah, M. Medraj, M.H. Idris, A.F. Lotfabadi, M. Daroonparvar, M.A.M. Yajid, Mater. Corros. 65, 999 (2014)

[33] S.X. Zhang, X.N. Zhang, C.L. Zhao, J.N. Li, S. Yang, C.Y. Xie, H.R. Tao, Y. Zhnag, Y.H. He, Y. Jiang, Y.J. Bian, Acta Biomater. 6, 626 (2010)

[34] K. Yang, J.S. Zhang, X.M. Zong, W. Liu, C.X. Xu, Acta Metall. Sin. (Engl. Lett.) 30, 464 (2017)

[35] G.L. Song, Corros. Sci. 49, 1696 (2007)

[36] J. Wang, Y.N. Zhang, P. Hudon, I.H. Jung, M. Medraj, P. Chartrand, J. Alloys Compd. 639, 593 (2015)

[37] T. Kokubo, H. Takadama, Biomaterials 27, 2907 (2006)

[38] Z.M. Shi, M. Liu, A. Atrens, Corros. Sci. 52, 579 (2010)

[39] S. Berbeni, V. Favier, M. Berveiller, Comput. Mater. Sci. 39, 96 (2007)

[40] Z.Y. Liu, X.Q. Jiang, F. Mu, H.D. Li, Light Met. 12, 59 (2008)

[41] S.R. Agnew, M.H. Yoo, C.N. Tome, Acta Mater. 49, 4277 (2001)

[42] D. Tie, F. Feyerabend, N. Hort, D. Hoeche, K.U. Kainer, R. Willumeit, W.D. Mueller, Mater. Corros. 65, 569 (2014)

[43] M. Andrei, A. Eliezer, P.L. Bonora, E.M. Gutman, Mater. Corros. 53, 455 (2002)

[44] N. Aung, W. Zhou, Corros. Sci. 52, 589 (2010)

[45] J. Hofstetter, E. Martinelli, A.M. Weinberg, M. Becker, B. Mingler, P.J. Uggowitzer, J.F. Loffler, Corros. Sci. 91, 29 (2015)

[46] P. Saha, M. Roy, M.K. Datta, B. Lee, P.N. Kumta, Mater. Sci. Eng. C 57, 294 (2015)

[47] K.D. Ralston, N. Birbilis, C.H.J. Davies, Scr. Mater. 63, 1201 (2010)

[48] S. Gollapudi, Corros. Sci. 62, 90 (2012)

[49] G. Ben-Hamu, D. Eliezer, L. Wagner, J. Alloys Compd. 468, 222 (2009) 